\title{
The use of revascularization strategies in patients with acute coronary syndromes admitted to hospitals without catheterization facilities: Results from the ALERT-CZ registry
}

\author{
Petr Widimskýa, Jana Zvárováb, Zdeněk Monhartc, \\ Petr Janskýd jménem řešitelů registru ALERT-CZ
}

\author{
a III. interní-kardiologická klinika, Kardiocentrum 3. lékařské fakulty Univerzity Karlovy a Fakultní nemocnice \\ Královské Vinohrady, Praha, Česká republika \\ ${ }^{b}$ EuroMISE centrum, Ústav informatiky, Akademie věd ČR, Praha, Česká republika \\ 'Interní oddělení, Nemocnice Znojmo, Znojmo, Ceská republika \\ ${ }^{d}$ Kardiochirurgická klinika, 2. lékařská fakulta Univerzity Karlovy a Fakultní nemocnice Motol, Praha, Česká republika \\ e Viz apendix pro úplný seznam řešitelů registru
}

\section{INFORMACE O ČLÁNKU}

Historie článku:

Došel do redakce: 20. 3. 2013

Přepracován: 22. 4. 2013

Prijat: 23. 4. 2013

Dostupný online: 28. 4. 2013

\section{Keywords:}

Acute coronary syndrome

Coronary angiography

Myocardial infarction

Non-PCl hospital

Percutaneous coronary

intervention

Revascularization

Unstable angina

\begin{abstract}
Aim: Percutaneous coronary intervention $(\mathrm{PCl})$ became the standard of care for patients (pts) with acute coronary syndromes (ACS). The Czech Republic is among European countries with well developed networks of $\mathrm{PCl}$ and non- $\mathrm{PCl}$ hospitals. Ample data about $\mathrm{PCl}$-treated pts is available from many registries. Much less is known about treatments and outcomes of ACS pts admitted to hospitals without cath-lab. ALERT-CZ registry was designed specifically to analyze these patients presenting to local non-PCI hospitals. The aim was to see, whether the ESC guidelines are implemented in these local, small hospitals.

Methods and results: A total of 6265 pts with first hospital admission for ACS has been enrolled in 32 Czech community hospitals without cath-lab during a 3-year period (7/2008-6/2011). The mean age was $69.7 \pm 12,3$ years, $39.5 \%$ were females, $35.4 \%$ had known diabetes mellitus, $76.0 \%$ hypertension, $28.3 \%$ previous myocardial infarction and $12.0 \%$ previous stroke. Twenty-five percent of pts had signs of acute heart failure (Killip II in 19.0\%, Killip III in 4.8\% and Killip IV in 1.1\%). The discharge diagnosis was ST-elevation myocardial infarction (STEMI) in $26.1 \%$, non-STEMI in $53.1 \%$ and unstable angina pectoris (UAP) in $20.9 \%$.

Emergent interhospital transport to coronary angiography (CAG) and $\mathrm{PCl}$ within $<12 \mathrm{~h}$ from symptom onset was indicated in $73.4 \%$ of STEMI pts, elective CAG was indicated in $15.9 \%$ of STEMI, CAG was not indicated in $9.9 \%$ of STEMI and $0.9 \%$ STEMI pts refused CAG. Among non-STE ACS pts CAG was performed within < $24 \mathrm{~h}$ in $16.2 \%$, between $24-72 \mathrm{~h}$ in $18.2 \%$, later in $38.1 \%$, not indicated in $22.7 \%$, refused by pts in $4.8 \%$. The median stay in the $\mathrm{PCl}$ center was 2.0 days and only $37 \%$ pts returned after $\mathrm{CAG}( \pm \mathrm{PCl})$ to the referring community hospital, the rest was discharged from $\mathrm{PCl}$ center directly to home.

Among STEMI pts the median time intervals were: pain - first medical contact (FMC) 120 min, FMC - community hospital door $30 \mathrm{~min}$, door-in-door-out for emergency transfer $23 \mathrm{~min}$. Thrombolysis was used in $0.4 \%$ of STEMI - in rare situations when immediate transfer was logistically not possible.

PCl was performed in $41.6 \%$ pts overall (65.9\% STEMI, 35.8\% non-STEMI and $26.4 \%$ UAP). CABG was performed in $2.9 \%$ pts overall $(2.1 \%, 3.1 \%$ and $3.6 \%$ per diagnosis). Detailed pharmacotherapy data as well as indirect comparison with a separate $\mathrm{PCl}$ centers registry is beyond the space frame of this abstract and will be presented. The overall in-hospital mortality was 7.2\%. Mortality per final diagnosis was $9.5 \%$ (STEMI), $8.7 \%$ (non-STEMI) and $0.5 \%$ (UAP). Mortality per age group was $16.2 \%$ ( $>80$ years), $8.0 \%$ ( $70-80$ years) and $2.4 \%$ ( $<70$ years). Conclusion: Patients presenting to non-PCI hospitals undergo revascularization procedures less frequently than those directly admitted to PCI centers. This may be related to baseline differences. The outcomes are influenced by these facts.
\end{abstract}

Adresa: Prof. MUDr. Petr Widimský, DrSc., FESC, FACC, III. interní-kardiologická klinika, Kardiocentrum 3. lékařské fakulty Univerzity Karlovy a Fakultní nemocnice Královské Vinohrady, Ruská 87, 10000 Praha 10, e-mail: petr.widimsky@fnkv.cz DOI: 10.1016/j.crvasa.2013.04.007 
Klíčová slova:

Akutní koronární syndrom Infarkt myokardu

Koronarografie

Nemocnice bez vybavení pro PCI

Nestabilní angina pectoris

Perkutánní koronární intervence

Revaskularizace
SOUHRN

Cíl: Perkutánní koronární intervence (PCI) se stala standardem péče o pacienty s akutními koronárními syndromy (AKS). Česká republika patří mezi evropské země s dobře propracovanou sítí spolupracujících nemocnic provádějících $\mathrm{PCl}$ a nemocnic, které tento výkon neprovádějí. Z řady registrů je $\mathrm{k}$ dispozici množství údajů o pacientech léčených pomocí $\mathrm{PCl}$. Mnohem méně se toho ví o způsobu léčby a výsledném stavu pacientů s AKS hospitalizovaných v nemocnicích bez katetrizačních sálů. Cílem registru ALERT-CZ bylo konkrétně analyzovat údaje těchto pacientů dopravených do místních nemocnic neprovádějicích $\mathrm{PCl}$ a zjistit, zda se v místních, malých nemocnicích uplatňují doporučené postupy Evropské kardiologické společnosti.

Metody a výsledky: Do projektu bylo zařazeno celkem 6265 pacientů poprvé hospitalizovaných pro AKS ve 32 českých komunitních nemocnicích bez katetrizačních sálủ během třiletého období (7/2008-6/2011). Průměrný věk těchto pacientů byl 69,7 $\pm 12,3$ roku, ve 39,5 \% šlo o ženy, 35,4 \% mělo diagnózu diabetes mellitus, 76,0 \% hypertenzi, 28,3 \% již dřive prodělalo infarkt myokardu a 12,0 \% cévní mozkovou príhodu. Pětadvacet procent pacientů vykazovalo známky akutního srdečního selhání (Killipova tř́ída II v 19,0\%, třída III v 4,8 \% a třída IV v 1,1 $\%$ př́ipadů). Diagnózou při propuštění byl infarkt myokardu s elevací úseku ST (STEMI) ve $26,1 \%$, infarkt myokardu bez elevací úseku ST (non-STEMI) v 53,1 \% a nestabilní angina pectoris (NAP) ve 20,9 \% př́ípadů. Naléhavý převoz mezi nemocnicemi k provedení koronarografie a $\mathrm{PCl}$ do 12 hodin od nástupu symptomů byl indikován u 73,4 \% pacientů se STEMI, plánovaná koronarografie u 15,9 \% pacientů se STEMI; koronarografie nebyla indikována u 9,9\% pacientů se STEMI, a 0,9\% pacientů se STEMI odmítlo její provedení. Z pacientů s non-STE AKS byla koronarografie provedena do 24 hodin u 16,2 \%, mezi 24 a 72 hodinami u 18,2 \%, ještě později u 38,1 \%, koronarografie nebyla indikována u $22,7 \%$, provedení koronarografie odmítlo 4,8 \% pacientů. Průměrná délka pobytu v zařízení s možností provést $\mathrm{PCl}$ byla 2,0 dne a pouze $37 \%$ pacientů se po koronarografii $( \pm \mathrm{PCl}$ ) vrátilo do původní komunitní nemocnice, ostatní byli propuštěni př́mo domů. U pacientů se STEMI byl medián intervalů následující: bolest - první kontakt s lékařem (first medical contact - FMC) 120 min, FMC - dveře komunitní nemocnice 30 min, př́ijezd ke dveř́m komunitní nemocnice a odvoz rychlou záchrannou službou od dveří komunitní nemocnice 23 min. Trombolýza byla provedena u 0,4 \% pacientů se STEMI, a to ve vzácných prípadech, kdy nebyl z logistických důvodů okamžitý převoz z komunitní nemocnice možný.

Perkutánní koronární intervence byla provedena celkem u 41,6 \% pacientů ( $65,9 \%$ se STEMI, 35,8 \% non-STEMI a $26,4 \%$ s NAP). Koronární bypass (CABG) byl proveden celkem u 2,9 \% pacientů (2,1 \%, resp. 3,1 \% a 3,6 \% podle výše uvedených diagnóz). Podrobné údaje o farmakoterapii i neprímé porovnání se samostatnými registry zařízení s vybavením pro provádění $\mathrm{PCl}$ přesahují rozsah tohoto abstraktu a budou uvedeny jinde.

Celková nemocniční mortalita činila 7,2 \%. Mortalita podle konečné diagnózy byla 9,5 \% (STEMI), 8,7 \% (non-STEMI) a 0,5 \% (NAP). Hodnoty mortality podle věkových skupin byly 16,2 \% (> 80 let), 8,0 \% (70-80 let) a $2,4 \%$ (< 70 let).

Závěr: Pacienti přivezení do nemocnic nevybavených pro provádění $\mathrm{PCl}$ absolvují revaskularizační výkony méně často než nemocní transportovaní prímo do nemocnic s katetrizačními sály. To může souviset s rozdíly ve vstupní charakteristice a výsledky mohou být těmito skutečnostmi ovlivněny.

○ 2013, ČKS. Published by Elsevier Urban and Partner Sp. z o.o. All rights reserved.

\section{Introduction}

Percutaneous coronary intervention $(\mathrm{PCl})$ became the standard of care for patients with acute coronary syndromes (ACS). The European Society of Cardiology (ESC) guidelines [1] recommend emergent (primary) $\mathrm{PCl}$ as the initial reperfusion therapy for all patients with ST-segment elevation acute myocardial infarction (STEMI), who present within $12 \mathrm{~h}$ from symptom onset and in whom such therapy can be initiated within 120 min from diagnostic 12-lead electrocardiogram (ECG). ESC guidelines for non-ST elevation ACS [2] recommend acute coronary angiography (with $\mathrm{PCl}$ whenever indicated) within $<2 \mathrm{~h}$ from hospital admission for high risk non-STE ACS and within $<24-72 \mathrm{~h}$ for those at intermediate risk.

Ample data about PCl-treated pts is available from many registries [3-9]. Much less is known about treatments and outcomes of ACS pts admitted to hospitals without cath-lab. Thus, the ALERT-CZ (Acute coronary syndromes - Longitudinal Evaluation of Real-life Treatment in non$-P C l$ hospitals in the (zech Republic) registry was designed specifically to analyze these pts presenting to local non-PCI hospitals. The aim was to see, whether the ESC guidelines are implemented in these local, small hospitals.

\section{Methods}

The Czech Republic is one of the European countries with well developed networks of $\mathrm{PCl}$ and non-PCl hospitals. The country population 10.5 million is served by $22 \mathrm{PCl}$ centers adequately distributed across all 13 counties. All $22 \mathrm{PCl}$ centers routinely offer non-stop (24/7) PCI services.

The ALERT-CZ registry enrolled 6265 patients with their first hospital admission for ACS in 32 Czech community hospitals without catheterization facilities during a 3-year period (July 1, 2008-June 30, 2011). The baseline characteristic of the enrolled patients is described in Table 1.

The registry was organized and coordinated by the Cardiocenter, Third Faculty of Medicine, Charles University Prague. Data was collected via a dedicated electronic case report form prepared and managed by the EuroMISE center of Charles University and Academy of Sciences of the Czech Republic. The patients baseline characteristics, pharmacotherapy, revascularization therapy and in-hospital outcomes were registered.

\section{Statistical methods}

The paper presents some results of descriptive statistics calculated from data of all ACS patients and in sub- 
Table 1 - The key baseline characteristic of ALERT-CZ patients.

\begin{tabular}{|l|l|l|l|l|}
\hline & All ACS patients & STEMI & Non-STEMI & UAP \\
\hline $\mathbf{n}=$ & 6265 & $1630(\mathbf{2 6 . 1} \%)$ & $\mathbf{3 3 1 9}(\mathbf{5 3 . 1} \%)$ & $\mathbf{1 3 0 6}(\mathbf{2 0 . 9 \% )}$ \\
\hline Mean age (SD) & $69.7(12.3)$ & $66.3(13.2)$ & $71.3(12.0)$ & $69.9(11.3)$ \\
\hline Females & $39.5 \%$ & $32.4 \%$ & $41.9 \%$ & $41.9 \%$ \\
\hline Diabetes mellitus & $35.4 \%$ & $26.0 \%$ & $39.5 \%$ & $36.4 \%$ \\
\hline Hypertension & $76.0 \%$ & $63.7 \%$ & $78.2 \%$ & $85.8 \%$ \\
\hline Previous myocardial infarction & $28.3 \%$ & $15.0 \%$ & $29.7 \%$ & $41.3 \%$ \\
\hline Previous stroke & $12.0 \%$ & $8.6 \%$ & $13.7 \%$ & $11.7 \%$ \\
\hline Killip II on admission & $19.0 \%$ & $16.1 \%$ & $21.6 \%$ & $16.2 \%$ \\
\hline Killip III on admission & $4.8 \%$ & $4.4 \%$ & $6.3 \%$ & $1.5 \%$ \\
\hline Killip IV on admission & $1.1 \%$ & $2.2 \%$ & $1.0 \%$ & $0.0 \%$ \\
\hline
\end{tabular}

groups of STEMI, non-STEMI a UAP patients. Most of basic statistical characteristics are expressed in percentages - no inductive statistical methods are presented in this paper.

\section{Results}

\section{In-Hospital outcomes}

The overall in-hospital mortality was $7.2 \%$. Mortality per final diagnosis was 9.5\% (STEMI), 8.7\% (non-STEMI) and $0.5 \%$ (UAP). Mortality per age group was $16.2 \%$ (> 80 years), $8.0 \%$ (70-80 years) and $2.4 \%$ (< 70 years). Mortality per sex was $5.8 \%$ (males) and $9.3 \%$ (females). Mortality in revascularized (PCl/CABG) patients was $2.1 \%(n=$ $2725)$, and in non-revascularized $11.3 \%(n=3468)$. Mortality data in additional subgroups are in Table 2.

A new stroke during this hospital stay occurred in $0.6 \%$ of patients. Cardiogenic shock developed during the hospital stay in $4.9 \%$ of patients ( $8.7 \%$ STEMI, $4.8 \%$ non-STEMI and $0.4 \%$ UAP) - on top of those $1.1 \%$ patients in whom the shock was present upon initial presentation. The clinical diagnosis of recurrent myocardial infarction during the hospital stay was done in $2.3 \%$ of patients. Among the patients transferred to $\mathrm{PCl}$ centers, the mean stay in the $\mathrm{PCl}$ center was $2.9 \pm 3.1$ days and only $37 \%$ pts

\section{Table 2 - Mortality in subgroups.}

\begin{tabular}{|l|l|l|l|}
\hline Mortality (\%) & All & $\begin{array}{l}\text { Revascularized } \\
\text { (PCI/CABG) }\end{array}$ & $\begin{array}{l}\text { Non- } \\
\text { revascularized }\end{array}$ \\
\hline STEMI & 9.5 & 4.1 & 20.9 \\
\hline non-STEMI & 8.7 & 1.0 & 13.6 \\
\hline UAP & 0.5 & 0.0 & 0.7 \\
\hline Age $<70$ years & 2.4 & 0.4 & 4.7 \\
\hline Age 70-80 years & 8.0 & 3.2 & 11.3 \\
\hline Age $>80$ years & 16.2 & 6.9 & 19.5 \\
\hline Males & 5.8 & 1.7 & 10.0 \\
\hline Females & 9.3 & 2.8 & 13.0 \\
\hline
\end{tabular}

returned after CAG $( \pm \mathrm{PCl})$ to the referring community hospital, the rest was discharged from $\mathrm{PCl}$ center directly to home. $\mathrm{PCl}$ was performed in $41.6 \%$ pts overall $(65.9 \%$ STEMI, 35.8\% non-STEMI and $26.4 \%$ UAP). CABG was performed in $2.9 \%$ pts overall $(2.1 \%, 3.1 \%$ and $3.6 \%$ per diagnosis).

\section{STEMI subgroup}

The emergent interhospital transport to coronary angiography (CAG) and $\mathrm{PCl}$ within $<12 \mathrm{~h}$ from symptom onset was indicated in $73.4 \%$ of STEMI pts, elective CAG was indicated in $15.9 \%$ of STEMI, CAG was not indicated in $9.9 \%$ of STEMI and $0.9 \%$ STEMI pts refused CAG. The mean time intervals were: pain - first medical contact (FMC) $450 \pm 1410$ min (median $120 \mathrm{~min}$ ), FMC - community hospital door 44 \pm 60 min (median $30 \mathrm{~min}$ ), door-in-door-out for emergency transfer $57 \pm 167 \mathrm{~min}$ (median $23 \mathrm{~min}$ ). Thrombolysis was used in $0.4 \%$ of STEMI - in rare situations when immediate transfer was logistically not possible.

\section{Non-STE ACS subgroup}

Among non-STE ACS pts CAG was performed within $<24$ $h$ in $16.2 \%$, between $24-72 \mathrm{~h}$ in $18.2 \%$, later in $38.1 \%$, not indicated in $22.7 \%$, refused by pts in $4.8 \%$.

\section{Discussion}

\section{Study limitations}

The main study limitation is that in most hospitals the patient enrollment was not done on a consecutive way. Some hospitals enrolled almost all their ACS patients, while others only a small proportion. Furthermore, this registry cannot provide complete picture about ACS treatment in the country because patients with STEMI or with severe non-STEMI (e.g. complicated by acute heart failure and ST depressions) who call the emergency medical service number 155 are usually bypassing the nearest non- $\mathrm{PCl}$ hospital and are directly admitted to a $\mathrm{PCl}$ center. Thus, the population presented in this manuscript is largely composed from those ACS patients who presented themselves (or by a family member) to the nearest hospital. 


\section{Reperfusion treatment for STEMI}

In general, the proportion of patients with STEMI referred for primary reperfusion was lower than expected. The explanation has three components: (1) the most clinically apparent STEMI patients bypassed these non-PCI hospitals as mentioned above, (2) many of the STEMI patients treated conservatively presented after $>12 \mathrm{~h}$ from symptom onset, (3) some patients (usually the very elderly) presented with atypical symptoms and/or had multiple co-morbidities and were thus considered not suitable for transfer to a $\mathrm{PCl}$ center.

\section{Conclusion}

Patients presenting to non-PCI hospitals undergo revascularization procedures less frequently than those directly admitted to $\mathrm{PCl}$ centers. This may be related to baseline differences. The outcomes are influenced by these facts.

\section{Acknowledgements}

This registry was supported by an unrestricted educational grant from Sanofi. We acknowledge the help of investigators in numerous non- $\mathrm{PCl}$ hospitals (their list is in the Appendix) and the administrative help of Mrs. Marta Krskova.

\section{Appendix}

The list of participating hospitals and investigators with number of enrolled patients in these hospitals:

\begin{tabular}{|c|c|c|}
\hline Investigator: & Hospital: & $\begin{array}{l}\text { Pts } \\
\text { enrolled: }\end{array}$ \\
\hline MUDr. Pavel Ježil & Nemocnice Chomutov & 53 \\
\hline MUDr. Ivana Kellnerová & Svitavská nemocnice & 118 \\
\hline MUDr. Jitka Kobrlová & $\begin{array}{l}\text { Masarykova městská } \\
\text { nemocnice v Jilemnici }\end{array}$ & 119 \\
\hline MUDr. Pavel Třeštík & Kroměřížská nemocnice & 647 \\
\hline MUDr. Michaela Melounová & Nemocnice Sušice & 87 \\
\hline MUDr. Josef Štumar & Nemocnice Třebíč & 159 \\
\hline MUDr. Josef Pola & Nemocnice Tanvald & 93 \\
\hline MUDr. Hana Grünfeldová & $\begin{array}{l}\text { Městská nemocnice } \\
\text { Čáslav }\end{array}$ & 164 \\
\hline MUDr. Olga Šantorová & $\begin{array}{l}\text { Rokycanská } \\
\text { nemocnice }\end{array}$ & 153 \\
\hline MUDr. Zdeněk Monhart, Ph.D. & Nemocnice Znojmo & 567 \\
\hline MUDr. Martina Kalová & $\begin{array}{l}\text { Městská nemocnice } \\
\text { v Litoměřicích }\end{array}$ & 163 \\
\hline MUDr. Kamil Zeman, Ing. & Nemocnice ve Fr.-Místku & 402 \\
\hline MUDr. Jakub Tocháček & Stodská nemocnice & 84 \\
\hline MUDr. Veronika Sedláková & $\begin{array}{l}\text { Oblastní nemocnice } \\
\text { Kladno }\end{array}$ & 273 \\
\hline MUDr. Gabriel Marcinek & Nemocnice Slaný & 173 \\
\hline
\end{tabular}

\begin{tabular}{|c|c|c|}
\hline Investigator: & Hospital: & $\begin{array}{l}\text { Pts } \\
\text { enrolled: }\end{array}$ \\
\hline Doc. MUDr. Josef Jandík, CSc. & $\begin{array}{l}\text { Oblastní nemocnice } \\
\text { Náchod }\end{array}$ & 76 \\
\hline Doc. MUDr. Karel Sochor, CSc. & $\begin{array}{l}\text { Jessenia, a. S., } \\
\text { Nemocnice Beroun }\end{array}$ & 36 \\
\hline MUDr. Pavel Šíma & $\begin{array}{l}\text { Oblastní nemocnice } \\
\text { Mladá Boleslav }\end{array}$ & 915 \\
\hline MUDr. Michal Hondl & $\begin{array}{l}\text { Krajská zdravotní, a. s., } \\
\text { Nemocnice Děčín }\end{array}$ & 74 \\
\hline MUDr. Jan Vohralík & $\begin{array}{l}\text { Karlovarská krajská } \\
\text { nemocnice, a. s., } \\
\text { Nemocnice Cheb }\end{array}$ & 311 \\
\hline MUDr. Oldřich Honců & $\begin{array}{l}\text { Panochova nemocnice } \\
\text { Turnov }\end{array}$ & 146 \\
\hline MUDr. Kamil Tachir & $\begin{array}{l}\text { Nemocnice Nové } \\
\text { Město na Moravě }\end{array}$ & 277 \\
\hline MUDr. Libor Horáček & $\begin{array}{l}\text { Nemocnice sv. Zdislavy, } \\
\text { a. s., Velké Meziříčí }\end{array}$ & 16 \\
\hline MUDr. David Gerber & $\begin{array}{l}\text { Domažlická } \\
\text { nemocnice }\end{array}$ & 201 \\
\hline MUDr. Pavel Sábl & $\begin{array}{l}\text { Nemocnice } \\
\text { s poliklinikou } \\
\text { v Semilech }\end{array}$ & 162 \\
\hline MUDr. Hana Froňková & $\begin{array}{l}\text { Městská nemocnice } \\
\text { PRIVAMED } \\
\text { Healthia Rakovník }\end{array}$ & 76 \\
\hline MUDr. Vratislav Dědek & $\begin{array}{l}\text { Orlickoústecká } \\
\text { nemocnice }\end{array}$ & 127 \\
\hline MUDr. Tomáš Mičkal & Nemocnice Hranice & 11 \\
\hline MUDr. Ivan Andr & $\begin{array}{l}\text { Oblastní nemocnice } \\
\text { Trutnov }\end{array}$ & 71 \\
\hline MUDr. Vladimír Kapal & $\begin{array}{l}\text { Uherskohradištská } \\
\text { nemocnice }\end{array}$ & 457 \\
\hline MUDr. Jan Švejda & $\begin{array}{l}\text { Nemocnice } \\
\text { Milosrdných sester } \\
\text { Karla Boromejského } \\
\text { v Praze }\end{array}$ & 17 \\
\hline MUDr. Jan Semrád & $\begin{array}{l}\text { Nemocnice } \\
\text { sv. Alžběty, Louny }\end{array}$ & 37 \\
\hline
\end{tabular}

\section{References}

[1] P.G. Steg, S.K. James, D. Atar, et al., ESC Guidelines for the management of acute myocardial infarction in patients presenting with ST-segment elevation, European Heart Journal 33 (2012) 2569-2619.

[2] C.W. Hamm, J.P. Bassand, S. Agewall, et al.; ESC Committee for Practice Guidelines, ESC Guidelines for the management of acute coronary syndromes in patients presenting without persistent ST-segment elevation: The Task Force for the management of acute coronary syndromes (ACS) in patients presenting without persistent ST-segment elevation of the European Society of Cardiology (ESC), European Heart Journal 32 (23) (2011) 2999-3054.

[3] K. Szummer, P. Lundman, S.H. Jacobson, et al., SWEDEHEART, Relation between renal function, presentation, use of therapies and in-hospital complications in acute coronary syndrome: data from the SWEDEHEART register, Journal of Internal Medicine 268 (1) (2010) 40-49. 
[4] C.J. Terkelsen, J.F. Lassen, B.L. Nørgaard, et al., Mortality rates in patients with ST-elevation vs. non-ST-elevation acute myocardial infarction: observations from an unselected cohort, European Heart Journal 26 (1) (2005) 18-26.

[5] P. Widimsky, M. Zelizko, P. Jansky, et al., CZECH investigators, The incidence, treatment strategies and outcomes of acute coronary syndromes in the "reperfusion network" of different hospital types in the Czech Republic: results of the Czech evaluation of acute coronary syndromes in hospitalized patients (CZECH) registry, International Journal of Cardiology 119 (2) (2007) 212-219.

[6] K.A. Fox, O.H. Dabbous, R.J. Goldberg, et al., Prediction of risk of death and myocardial infarction in the six months after presentation with acute coronary syndrome: prospective multinational observational study (GRACE), BMJ 333 (2006) 1091-1094.

[7] M. Gottwik, R. Zahn, R. Schiele, et al. Differences in treatment and outcomes of patients with acute myocardial infarction admitted to hospitals with to without departments of cardiology; results from the pooled data of the Maximal Individual Therapy in Acute Myocardial Infarction (MITRA 1+2) Registries and the Myocardial Infarction Registry (MIR), European Heart Journal 22 (2001) 1794-1801.

[8] J.S. Birkhead, C. Weston, D. Lowe, Impact of specialty of admitting physician and type of hospital on care and outcome for myocardial infarction in England and Wales during 2004-5: observational study, BMJ 332 (2006) 1306-1311.

[9] H.K. Kim, M.H. Jeong, Y. Ahn, et al.; Korea Acute Myocardial Infarction Registry Investigators; Korea Acute Myocardial infarction Registry (KAMIR) Study Group of Korean Circulation Society, A new risk score system for the assessment of clinical outcomes in patients with non-ST-segment elevation myocardial infarction, International Journal of Cardiology 145 (3) (2010) 450-454. 